\title{
Genealogy of the Westerdijk academic family
}

\author{
Patricia Faasse
}

Accepted: 15 January 2019/Published online: 30 January 2019

(C) The Author(s) 2019

\begin{abstract}
Utrecht University and the Royal Academy of Arts and Sciences have designated the year 2017 the 'Westerdijk-year'. On a number of occasions during that year, events have been organised to commemorate the fact that exactly hundred years ago, Johanna Westerdijk was inaugurated as the first female professor in the Netherlands. The former CBS seized the moment and changed its name into the 'Westerdijk Fungal Biodiversity Institute'. At the grand re-opening of the institute, the mayor of Utrecht unveiled a bronze statue of Johanna Westerdijk, that now stands in front of the building, allowing her to continue to oversee her legacy at the institute. The Westerdijk-year has been full of festivities. There have been countless lectures, several exhibitions, a few specific Westerdijk walks, and of course, also some pub quizzes. And obviously, there have been gadgets. To name some very particular ones: a perfume with the scent of Amsterdam elms, T-shirts saying: 'even a fungus dies from a dull life' (a quote from Westerdijk), a delicate silver necklace and a beautifully decorated silk scarf. Another extraordinary product of the Westerdijk-year is an artistic graphic representation of her 'academic family'. In this article, I will elaborate on this representation. What does it show? And what can we learn from it?
\end{abstract}

Keywords Geneaological tree · Johanna Westerdijk · Brain circulation $\cdot$ Academic family

P. Faasse $(\bowtie)$

Rathenau Institute, Anna van Saksenlaan 51, 2593 HW The

Hague, the Netherlands

e-mail: p.faasse@rathenau.nl
Utrecht University and the Royal Academy of Arts and Sciences have designated the year 2017 the 'Westerdijkyear'. On a number of occasions during that year, events have been organised to commemorate the fact that exactly hundred years ago, Johanna Westerdijk was inaugurated as the first female professor in the Netherlands. The former CBS seized the moment and changed its name into the 'Westerdijk Fungal Biodiversity Institute'. At the grand re-opening of the institute, the mayor of Utrecht unveiled a bronze statue of Johanna Westerdijk that now stands in front of the building, allowing her to continue to oversee her legacy at the institute.

The Westerdijk-year has been full of festivities. There have been countless lectures, several exhibitions, a few specific Westerdijk walks, and also, of course, some pub quizzes and obviously there have been gadgets. To name some very particular ones: a perfume with the scent of Amsterdam elms, T-shirts saying: 'even a fungus dies from a dull life' (a quote from Westerdijk), a delicate silver necklace and a beautifully decorated silk scarf.

Another extraordinary product of the Westerdijk-year is an artistic graphic representation of her 'academic family' (Fig. 1). In this article, I will elaborate on this representation. What does it show? And what can we learn from it?

\section{Five branches}

Westerdijk educated $56 \mathrm{PhD}$ students, of which almost half were female. This group constitutes the first generation. Yet Westerdijks academic family tree not only portrays these 56 students, but also their academic 


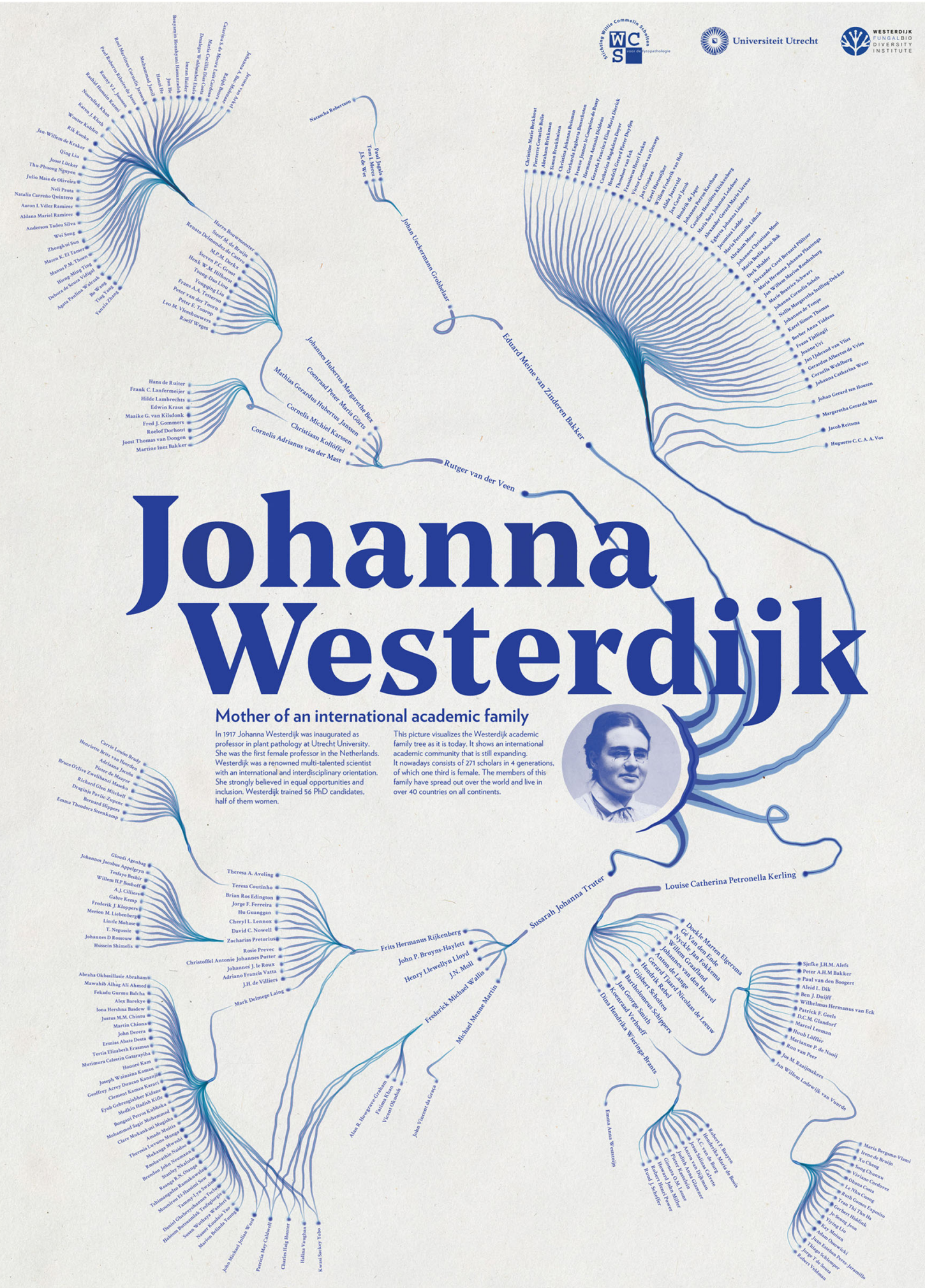

Fig. 1 Geneaological tree of the academic family of Prof. Johanna Westerdijk 
descendants, and again their descendants, and again their descendants. We have been able to trace Westerdijk's academic 'offspring' up into the fourth generation.

The idea is simple: of Westerdijk's $56 \mathrm{PhD}$ students, 8 became professors themselves. They also educated $\mathrm{PhD}$ students, of whom some also became professor, also educated $\mathrm{PhD}$ students, and so forth. The persons in the fourth generation - whose names are at the largest distance from the centre - have either just finished their $\mathrm{PhD}$, or are working on it right now. It is still too early to say who of them will become professor in the next generation. Other than the picture suggests therefore, the family tree is alive, and still moving - in directions still unknown.

The tree, which actually is designed to resemble mycelium-like threads emanating out from Westerdijk's photo in the centre, pictures 271 names, grouped together in five branches of different sizes and shapes. I will briefly characterize them.

\section{Johanna Westerdijk (Utrecht University/University of Amsterdam, the Netherlands, 56 family members)}

The branch at the top right of the picture represents Westerdijk's $\mathrm{PhD}$ students. It is by far the largest branch - no professor in this entire tree has ever educated so many $\mathrm{PhD}$ students as Westerdijk did.

If it were possible to ask them what doing a $\mathrm{PhD}$ with Westerdijk had been like, they presumably would start telling stories about how remarkable a woman she was. They would recall the friendly and hospitable atmosphere in Villa Java in Baarn, where they all did their research. Some maybe would recapitulate Westerdijk's slogan 'For fine minds, the art is, to mix work and parties'- a slogan that had been carved in stone above the entrance to the lecture hall. Some would be reminded of the traditions that getting a $\mathrm{PhD}$ was accompanied by: the hoisting of the flag, the three geese in the yard wearing white, blue and red bows around their necks, the planting of a tree in what gradually became a Doctors Wood, and the sounds of piano music, singing and laughter in the evening, when the content of the thesis had been recapitulated in rhyming couplets, as if in a fresh demonstration of competence, this time in self-mockery and self-irony, the motto being: 'If you can't play the fool, how can you ever be serious?' (Faasse 2008).

But we cannot - the members of the first generation have all passed away. Historical research, however, can tell us a few things about their academic fates. We know for example, that more than half of them stayed within an academic setting, and continued their careers either as a researcher or assistent within Villa Java in Baarn, or at one of the Dutch universities. One out of seven went to the Dutch Indies, to work at one of the many experiment stations (to carry out scientific research in the service of colonial plantation agriculture in sugarcane, tobacco, tea, rubber, coffee, cinchomna, indigo or oil palm). An equal part of them went to work in industry or in public service or they found employment as a teacher. This leads us to conclude that only very few members of this generation didn't capitalize on their academic training in plant pathology.

As stated earlier, 8 members of this branch also became professor. Their gender balance is shaped perfectly equal: four of them were women, four of them men.

Four of them did not educate $\mathrm{PhD}$ students: their names are therefore arranged at the lower end of the branch. Of this group, two were appointed professor in Indonesia in the early fifties (Huguette Vos and Jacob Reitsma). They had to leave their posts quickly after they had been appointed however, as a consequence of the Indonesian national politics. The third person in this group, Margaretha Mes, was appointed professor in botany at the University of Pretoria in 1944. Mes successfully introduced training courses in plant pathology in Pretoria, and thus cleared the soil for a next generation of plant pathologists to be planted there. She died from an incurable disease in 1959. And Johan ten Houten, the final member of this group, became the first professor of the newly established Institute for Phytopathology Research (IPO) in Wageningen in 1949. This institute was not part of Wageningen University (even though the two held good connections), and this might explain why he did not educate $\mathrm{PhD}$ students in those years.

The other four $\mathrm{PhD}$ students who were appointed professor have succesfully continued the academic family tree, in two geographically distinguished areas: the Netherlands and South-Africa.

\section{Louise Kerling (Utrecht University/University of Amsterdam, the Netherlands 57 family members)}

If one reads the family tree clockwise, starting from the Westerdijk $\mathrm{PhD}$ branch, one encounters at the bottom right the branch that is headed by Westerdijk's direct 
successor, professor Louise Kerling. Kerling finished her $\mathrm{PhD}$ in 1928 on the anatomy of 'Cercospora zonata,' a fungal plant pathogen. She continued her career as a high school teacher in the Dutch-Indies. In 1940, she was detained by the Japanese occupying forces into Camp Halmaheira in Semarang, where she also taught her fellow camp inhabitants. From 1946 onwards she worked at the Mycology and Potato Laboratory at the School of Agriculture in Wageningen until 1952 when she became professor in plant pathology. Like Westerdijk, she held chairs in plant pathology at two universities: Utrecht and Amsterdam. During the period of her professorship, between 1952 and 1970, she educated $13 \mathrm{PhD}$ students.

Three of them also came to be a professor - and together these three educated $26 \mathrm{PhD}$ students. Only one of them also became a professor, at Wageningen University and at Leiden University. At present, he has educated $18 \mathrm{PhD}$ students - but as stated, at this point, we are still counting.

\section{Susarah Truter (Pietermaritzburg, University of Kwazulu-Natal, South Africa, 85 family members)}

Again turning one step clockwise, at the bottom left, we encounter the Truter branch in South Africa. Susarah Truter, born in Aliwal Noord (South Africa) in 1910, finished her PhD research in Baarn in 1947. After her promotion, Truter was appointed as plant pathologist at the Western Province Fruit Research Laboratories at Stellenbosch. Soon she became senior lecturer in the newly established Faculty for Agriculture at the University of Natal. In 1956 she became professor of Plant Pathology and Microbiology at this university. Just five years later, Truter was elected Dean of the faculty, being the first woman Dean at a faculty of agriculture in the world. She retired in 1976 and left a largely grown and above all successful faculty. Truter never married, and just like a great number of her fellow woman $\mathrm{PhD}$ students, she always kept a good friendship with Westerdijk, who once visited her in Pietermaritzburg.

Truter educated six PhD students, of whom three also became a professor - all of them at the University of Natal. These three professors educated 23 $\mathrm{PhD}$ students, of whom three also became a professor. These three together have educated $56 \mathrm{PhD}$ students so far - still counting.

\section{Rutger van der Veen (Utrecht University, the Netherlands, 67 family members)}

At the top left of the family tree, we find the Van der Veen branch. After he finished his PhD in 1930, Van der Veen started working for the Philips Natural Laboratory in Eindhoven. He specialized in plant growth under artificial lightning. In 1960 he became professor by special appointment at Utrecht University, while he also kept working at the Philips Laboratory. In 1963 he was appointed as full professor in plant physiology at Utrecht University, a position he kept until 1970.

Van der Veen educated six PhD students, of whom two also became a professor: one in Utrecht, the other one in Wageningen University. Together these two professors educated $21 \mathrm{PhD}$ students, of whom one also became a professor. He has educated $39 \mathrm{PhD}$ students so far - still counting.

\section{Eduard Meine van Zinderen Bakker (Bloemfontein, University of the Free State, South Africa, 5 family members)}

In between the Van der Veen and the Westerdijk branches, we see a small branching of the tree: this is the Van Zinderen Bakker branch. He obtained his $\mathrm{PhD}$ in 1935. After his promotion, he taught biology in Apeldoorn. In 1947, he emigrated to South Africa, where he became a lecturer in botany at the University of the Free State. In 1963 he became Professor at the Department. In 1972, he also became Director of the newly established Institute of Environmental Sciences. He retired in 1988.

At the University of the Free State, van Zinderen Bakker educated one $\mathrm{PhD}$ student, who succeeded him as a professor at the same university. This professor educated three PhD students, of whom one became a professor in Johannesburg in 2006. In 2011 he moved to the University of Queensland, Australia. So far, this professor has educated one PhD student - to be continued.

\section{Two observations}

Gender balance

Johanna Westerdijk strongly believed in equal opportunities for all those willing to do science. She welcomed 
to her laboratory anyone willing to learn about plant pathology, fungi, disease processes or any other topic related to crop growth, plant-microbe interactions or plant protection. Without turning this belief into a distinct ideology or political programme, she vigorously rejected the idea that an academic career was to be reserved only for those with the appropriate academic training, or for those belonging to a group with a particular gender, nationality or racial origins. Her most loyal assistant for instance, a man who worked with her almost his entire life, had never attended a university. He was awarded a 'doctorate honoris causa' at Utrecht University in 1940.

It is no coincidence therefore, that the gender balance of Westerdijk's PhD students approached an ideal equilibrium. Despite her explicit claim, that gender should not be relevant as a criterion for selecting who was fit for academic life and who was not, she did notice that women had a hard time, when they wanted to enter university, or even when they had entered university. Unostentatiously, she encouraged them to pursue an academic career, most of the time by simply setting herself as an example. 'We don't need to be prudish or ladylike', she once said. 'We can do the job equally well - we sometimes do it even better'. The word 'role model' suits the way Westerdijk approached her female students.

In the next generations, the gender balance that Westerdijk had created disappears. The amount of female $\mathrm{PhD}$ students in the second generation drops to $5 \%$; in the third generation it raises to $25 \%$, and in the fourth again to $35 \%$. This leads us to - tentatively conclude that it takes a great deal of effort to reach or maintain an equal gender balance. Or, conversely: that Westerdijk has done an extraordinary job in this respect.

\section{International mobility}

Westerdijks belief in inclusiveness expresses itself in her professional attitude as well. Scientific progress, in her view, depended on international cooperation. Plant diseases simply don't stop at national borders - and fungi too, travel wherever they like. According to Westerdijk, a genuine plant pathologist, therefore, needed to have an international orientation. He or she needed to be willing to travel around and learn as much as possible about plant diseases and their causes all over the world.

Technical skills and cognitive capacities alone did not suffice to operate as a professional plant pathologist: one needed to have social skills as well. Westerdijk has always been proud of her talent to speak different languages and her ability to create warm, friendly relationships with all sorts of people. She communicated as easily with fellow scientists, as with farmers, industrialists, bulb growers, or policy makers. To her, these skills belonged to the profile of a true plant pathologist. 'One does not become a plant pathologist to become rich or famous', she once said. 'We do our work out of love and compassion.' Due to the international network she created, the small and rather insignificant fungal collection of the original Centraal Bureau voor Schimmelcultures could expand and raise to its present status: a worldrenowned microbial biological resource centre of living filamentous fungi, yeasts and bacteria.

When we look at the international mobility of $\mathrm{PhD}$ students in the four generations of this academic family, we recognize that Westerdijk's students successfully created new research centres for plant pathology elsewhere. In the Netherlands, we find her descendants at the universities of Utrecht, Amsterdam, Leiden and Wageningen. In South Africa, they have spread to the Universities of Orange Free State in Bloemfontein, the University of Natal in Pietermaritzburg, and the universities of Pretoria and Kaapstad.

Most striking however, is the international mobility of $\mathrm{PhD}$ students in the fourth generation, in particular within the present research groups in Wageningen and at the University of Natal. Within both research groups, a relatively large number of $\mathrm{PhD}$ students have been educated, or still are being educated (over $40 \mathrm{PhD}$ students). In the Wageningen group, chaired by Harro Bouwmeester (a 'descendant' from the Van der Veen branch), nearly $75 \%$ of the $\mathrm{PhD}$ students are international students: they come from countries like China, Taiwan, Brazil, Pakistan, Ethiopia, Lebanon, Iran, Argentina, Portugal or Colombia. In the university of Natal group, chaired by Mark Laing (a 'descendant' from the Truter branch), we see a similar pattern. Nearly $70 \%$ of the $\mathrm{PhD}$ students in this group come from African countries like Eritrea, Kenia, Malawi, Ethiopia, Mozambique, Uganda, Zambia, Nigeria, Ivory Coast, Burkina Faso or Rwanda. Also striking is the fact, that a large number of them return to their country of origin, once they have finished their $\mathrm{PhDs}$ - and thereby spread their knowledge and expertise further, and expand the family network to places all over the world.

It is impossible to ascribe the intensity of this present 'brain circulation' to the actions of Johanna Westerdijk. It does show however, that plant pathology still is an 
internationally oriented scientific discipline, as it used to be in Westerdijk times, and continues to be so. As the 'mother' of this academic family, she would certainly be pleased to see her children behave in her spirit.

\section{Final remark}

The names of all persons represented in this family tree have been accessed by information, that is publicly available on the internet, or that has been published in historical journals. We have tried to be as correct and complete as possible. It is however, quite unlikely that this information is entirely correct and complete.

In our view, the family tree is a living document - and ideally, even a first step towards the emergence of a 'family community'. We therefore encourage everyone who considers him- or herself as a member of this family, to reach out and contribute to the creation of this community.

Acknowledgments The geneaological research has been done by Bram Harkema, a student in the history of science at Utrecht University. The picture of the academic family tree has been designed by graphic designer Barend Wilschut. The work has been funded by the Willie Commelin Scholten Foundation for Phytopathology.

\section{Compliance with ethical standards}

Conflict of interest The author declares that she has no conflict of interest.

Human and animal rights No human and/or animal participants were involved in this research.

Open Access This article is distributed under the terms of the Creative Commons Attribution 4.0 International License (http:// creativecommons.org/licenses/by/4.0/), which permits unrestricted use, distribution, and reproduction in any medium, provided you give appropriate credit to the original author(s) and the source, provide a link to the Creative Commons license, and indicate if changes were made.

\section{Reference}

Faasse, P. (2008). In splendid isolation, a history of the Willie Commelin Scholten phytopathology laboratory 1894-1991 (pp. 100-105). Amsterdam: KNAW Press. 